\title{
Editorial
}

\section{Trends in PsychologylTemas em Psicologia: Panorama atual e perspectivas futuras}

É com enorme satisfação que a revista Trends in Psychology/Temas em Psicologia entrega para a comunidade acadêmica mais um volume. Neste número, algumas modificações foram implementadas, com vistas a alcançarmos, cada vez mais, um padrão de excelência. Os esforços que vêm sendo realizados centram-se em dois grandes eixos: 1) qualidade e agilidade na tramitação dos manuscritos submetidos; 2) internacionalização do periódico.

Em relação ao primeiro ponto, cabe destacar que este volume apresenta um tempo recorde de tramitação dos manuscritos, na história da Trends/Temas. Em média, o tempo de tramitação dos manuscritos, desde a sua chegada até o recebimento da primeira versão reformulada foi de quatro meses e três dias. Do mesmo modo, o tempo entre o recebimento do manuscrito e o aceite final foi igualmente satisfatório: cinco meses e dez dias. Essa agilidade no processo editorial está relacionada a um amplo trabalho de equipe realizado entre a editora-chefe, o editor-associado, a comissão-editorial e os pareceristas ad-hoc. Todos estes colegas têm contribuído significativamente para que a Trends/Temas atinja padrões internacionais na agilidade da tramitação dos manuscritos recebidos.

Outro ponto que cabe destacar são os esforços realizados com vistas à internacionalização do periódico. Recentemente, a revista Trends in Psychology/Temas em Psicologia encontra-se indexada na base de dados SCOPUS/Elsevier. Portanto, os manuscritos publicados estarão disponíveis numa das maiores bases de dados mundiais, o que aumentará consideravelmente a sua visibilidade. Outro ponto importante para o processo de internacionalização foi a adoção de um nome internacional para a revista. Agora a Temas em Psicologia passa a ser também intitulada Trends in Psychology, portando um ISSN próprio: $2358-1883$.

Com vistas a consolidar este projeto, gostaríamos de encorajar, cada vez mais, os autores a enviarem seus manuscritos em língua internacional (inglês ou espanhol). Além disso, enfatizamos que, caso seja do interesse do autor, o mesmo manuscrito pode ser publicado em mais de uma língua, conforme já realizado neste periódico, por exemplo, na Edição Especial sobre AIDS, 21(3), 2013, organizada pela professora Dra. Vera Sílvia Facciolla Paiva (USP-SP).

Todas as iniciativas que estão sendo adotadas têm como objetivo principal colocar a Trends in Psychology/Temas em Psicologia entre as melhores revistas brasileiras na área da Psicologia. Neste sentido, continuamos contando com a colaboração de todos os autores, pesquisadores e membros da comissão editorial que, juntos, muito têm auxiliado no desenvolvimento da revista Trends in Psychology/Temas em Psicologia.

A todos, nossos sinceros agradecimentos.

Terezinha Féres-Carneiro Editora-Chefe

Bruno Figueiredo Damásio Editor-Associado 